\title{
The Oral Epics of the Women of the Dandakaranya Plateau: A Preliminary Mapping
}

\author{
Chris A. Gregory
}

\section{INTRODUCTION}

The aim of this paper is to fill in a small but significant gap in the growing scholarship on the oral epics of India by means of a preliminary mapping of some of the oral epics sung by the women of the Dandakaranya (DNK) plateau of southern Chhattisgarh (formerly eastern Madhya Pradesh) and western Orissa. The approximate location of the DNK plateau is marked on figure 1 as a dotted circle. The approximate distribution of the women's oral epics is represented by the inner, solid circle. The women sing a number of different epics in this region but I restrict myself here to a brief discussion of three of them: Tija Jagar, which is sung during the wet season; Lachmi Jagar, which is sung during the cold season; and Bali Jagar, which is sung during the hot season.

The circles showing the distribution of the DNK epics are superimposed on a map from the volume Oral Epics in India (Blackburn et al., 1989). This landmark study has transformed scholarly understanding of the oral epic traditions of India because before it was published virtually nothing was known about them. The original map showed a north-south contrast in terms of distribution with most of the large supraregional epics found in the Hindi heartland of the north. But as Blackburn (1989: 18) noted at the time, 'these correlations are more a reflection of the incomplete state of research on these traditions than they are a reflection of the actual distribution of the traditions.' He speculated that when more traditions are reported the north-south contrast will disappear. Blackburn's speculation has turned out to be correct. The epic tradition in the DNK region almost bridges the gap between the Ellamma tradition of Andhra Pradesh and the Lorik-Canda of north-western Madhya Pradesh.

There is wide variety in the form and content of the epics described in Oral Epics in India but a number of common themes emerge. Firstly, men are either the sole or principal singers/tellers of the tales. Where women do sing they are invariably subordinate to their husbands or senior males. Secondly, the central themes of many of the epics concern war, conquest and destruction, and those epics of a sacred nature that are ritually enacted invariably have death as a central ritual theme. The deity worshipped in such rituals is usually a deified hero or heroine who died a tragic and/or undeserved death. Thirdly, the stories are episodic and lack the unity of the classic narrative. The stories are rarely, if ever, sung in full. Instead, the singer selects episodes from here and there to finish singing in the time allowed for the performance. Fourthly, the epics tend to have a subaltern flavour in that they are grounded in the local history of the 'little kingdom' of the region.

The women's epic tradition of the DNK plateau could not be more different. Firstly, the main singer is usually a woman although men are not excluded from becoming singers. This tradition is of interest because it is, for the most part, one performed by women for women about women, and there are no reported instances of such a tradition in Oral Epics in India. Secondly, birth and the reproduction of life are the central ritual themes rather than death and destruction. Violence is sung about but is of the domestic kind (e.g. wife bashing) rather than wars of conquest. Thirdly, the stories are sung in full when they are performed. The Lachmi Jagar, for example, has a classic narrative structure with a well-defined exposition, development, climax, denouement, and final resolution, and its remarkable unity as a story comes about because it is an elaborate allegory of the rice production process. Fourthly, whilst the women's epics have a subaltern flavour they are grounded in the general social relations of the patriarchal household rather than of the particular history of a 'little kingdom.' They are also grounded in the local ecology of the DNK region. This plateau region is defined by the cross that divides India east/west into rice-growing and millet-growing areas, and north/south into Indo-European and Dravidian speaking areas. Surprisingly, the 


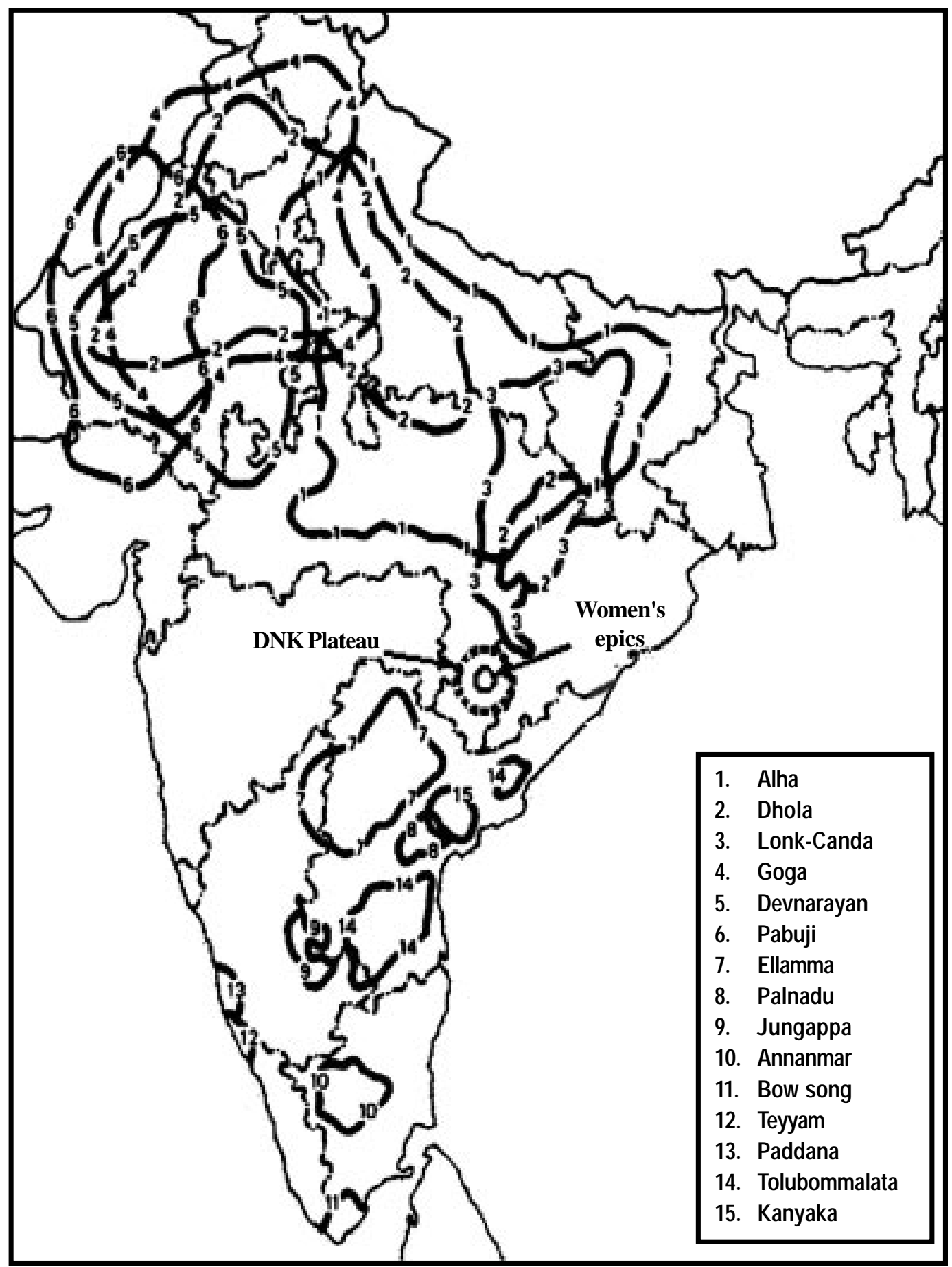

Fig. 1. Oral Epics of India

(adapted from Blackburn et al., 1989) 
linguistic frontier does not appear to be of any cultural significance insofar as understanding the epics is concerned. In the Lachmi Jagar epic, for example, the millet/rice distinction is of central importance for understanding the epic.

The aim of this paper is to develop some of these themes by means of a preliminary account of some ongoing research my colleagues and I are engaged in. This research is in its early stages and my remarks are provisional in nature. My principal concern is to stress how much we do not know about this tradition rather than how much we do know. As such, my concern is to pose questions for research rather than provide answers. The existence of this woman's tradition of oral epics obviously has theoretical implications for the study of subaltern consciousness in India but before these implications can be developed much more empirical work is needed, especially in western Orissa.

\section{A GENERAL DESCRIPTION OF THREE EPICS}

The oral tradition of the women of the DNK plateau is extraordinarily rich and diverse. It is mainly in the form of song. Some of these songs take a few minutes to sing, some take a few hours, and a few take months; many songs are sung solely for purposes of entertainment but some are sung during religious rituals for serious religious purposes. While not enough is known about this tradition to attempt a classification of the kind Flueckiger (1996) has done for a neighbouring district in the Chhattisgarh plain, it is clear that the three epics I will be concerned with here - the Lachmi Jagar and Tija Jagar epics of Bastar District in the state of Chhattisgarh, and the Bali Jagar epic of Nowrangpur District in Orissa - belong to a class of their own. These are all 'epics' in the sense that they take anywhere from one week to three months to perform. They also stand apart because the performance of the song is a sacred ritual sung by women who play a musical bow of a kind that is unique to this region.

The performance of Lachmi Jagar seems to be restricted to the Halbi-speakers of Bastar District in the state of Chhattisgarh. Performances take place in the major centres of Jagdalpur $(19.06 \mathrm{~N}, 82.03 \mathrm{E})$ and Kondagaon (19.6N, 81.7E), and in many of the villages in the sub-districts of Jagdalpur, Kondagaon, Narayanpur, Dantewada and Bijapur. Lachmi Jagar is a ritually-enacted myth performed by women for women but not exclusively so. Men may attend the celebrations and some men have even become singers. The word jagar can be translated as 'wake' in the strict religious sense of that term. On the final day of the ritual, abstinence from sleep and food is practised as a religious observance. The ritual also has entertainment value. This is especially so on the last day when the ritual reaches its climax and the divine marriage of Mahalakhi (also called Lachmi in Halbi and Lakshmi in Hindi) and Narayan is performed. This wedding follows the general form of an actual wedding and, as such, involves much frivolity and dancing. The jagar can be hosted by a community or an individual household. The men of the hosting household are obliged to participate as ritual actors because they, along with their wives, assume the role of the central characters in the epic as it is sung. People say that the general purpose of the ritual is to ensure wealth.

The distribution of performance of the Tija Jagar epic (also called 'Dhankul') seems to be the same as that of the Lachmi Jagar epic. However, whereas Lachmi Jagar is a cold season ritual, Tija Jagar is performed in the wet season. The length of the performance varies from singer to singer and region to region and can last anywhere from two weeks to two months. In all cases, however, the ritual finishes on the third (tij) day of the rising moon of Bhadon (AugustSeptember) from whence comes the name 'Tija Jagar.' One of the central figures in this song is Parbati but the story, which covers seven generations, does not admit of simple summary save to say that it is a sad song sung on a happy occasion. In one version of the song a co-wife of Parbati commits suicide because of the bad treatment she receives from Parbati. Unlike the performance of Lachmi Jagar, which tends to be a sombre occasion when women sit around for hours listening to the singing in silent contemplation, a performance of Tija Jagar is a very happy occasion with much audience participation. The audience continually demands that the singers interrupt the singing of the epic to sing a 'chakna.' The literal meaning of this word is 'snack' but here it means a short humorous song of five minutes or so in length. It is sung to a different beat and lifts the mood of the performance. Members of the audience actively participate in the proceedings and often 
take over the playing of the musical bow, something that never happens during a performance of Lachmi Jagar. The effect of these musical 'snacks' is to stretch out the length of the performance; but, at the same time, the singers know that it must finish on a fixed day, and balance the fun and the serious singing so that they finish on time.

The Bali Jagar epic of Nowrangpur District in Orissa is performed during the hot season where it is sung by Desiya speakers (a dialect of Oriya, an Indo-European language) and Pengo speakers (a Dravidian language). Very little is known about this tradition and my comments are based on a brief visit we made to Nowrangpur (19.2N, 82.5E) and surrounding villages. The Bali Jagar epic ritual (literally 'sand-bringing' ritual) of Nowrangpur District, Orissa, lasts for up to three months and is always held in the hot-season months of February to May when there is little farm work to do. At the completion of the ritual, wooden images of Bhima and Bhimin are installed in a sacred grove on the outskirts of the village. A village will host the ritual every twelve years and the sign that this time has come, according to tradition, is when the images of Bhima and Bhimin rot, fall towards one another, and touch.

This ritual varies greatly over the western Orissa area but for those rituals that have Bhima as the central ritual focus then we can be sure that the ritual has something to do with droughts and the hope of rain. Bhima is always associated with drought-breaking rains in the mythology of the DNK region, even though he is not himself the god of rain.

Hosting a Bali Jagar ritual is a very costly affair and involves the participation of a whole village, both men and women. The cost of the ritual is funded by a levy imposed on all members of the village according to the amount of land owned. Most of the performances I have witnessed of Lachmi Jagar and Tija Jagar, by contrast, have been small-scale affairs hosted by a householder or a community with women the principal participants.

In all three cases the songs seem to reach a narrative climax with the description of a divine marriage. In the Tija Jagar epic, for example, the climax is the marriage of Baligaura to Mahadev in a lake full of water. When Mahadev's first wife, Parbati, learns of the marriage she beats Baligaura and evicts her from the house. Unable to find food Baligaura drowns herself. While the meaning of the story poses an interpretative challenge, it is clear that the epic has the idea of water as a central symbol, which is hardly surprising given that the epic is performed in the wet season.

The narrative climax of Lachmi Jagar is the wedding of Mahalakhi and Narayan. Unlike Tija Jagar where there is little emphasis on ritual, this wedding is the ritual climax of the performance and is always held on a Thursday. This ritual is a symbolic harvest and the symbolism is obvious to all. The villagers go to a rice field, cut a few stalks, and dress them up to represent Mahalakhi. The stalks of grain are wrapped in a 'sari' and decorated with 'bangles,' 'earrings,' and other things worn by a bride. The image is then carried back to the village and the ritual marriage is performed. This may take up to ten hours or more to complete and follows the same pattern as a normal wedding. It ends with singing and dancing that often goes late into the night. Meanwhile, the singers stay up all night singing so that they may complete their story by morning.

Two other marriages are enacted during Lachmi Jagar: the wedding of Bhima and the wedding of a mango tree. The reason for the former is fully explained in the story that is sung whilst it is being held. Mahadev's rice crop is in danger of dying for want of rain. He consults an astrologer who tells him to arrange Bhima's wedding. Bhima agrees to the wedding but only on condition that Meng (literally 'cloud'), the god of the monsoon rain, is invited. Meng (Mahalakhi's father) arrives on the last day of the wedding in the form of rainstorm and the crops are saved. The symbolism of the mango wedding is more of an interpretative challenge because there is no local exegesis for it, save the traditional one that mango trees must be symbolically married each year prior to eating the ripe fruit. However, comparative ethnographic evidence suggests a clear association between mangos and conception (Nair, 1996: 469-73).

\section{THE SINGERS AND THEIR MUSICAL BOW}

While there are many variations both within and between the women's oral epics of the DNK plateau, two invariant features stand out. The first is that the principal singers are, for the most part, women. The singers perform in teams of three. The senior player is called a path gurumai and her assistants are called cheli gurumai. At 
any one time two singers sit playing hunting bows; the third singer either rests or sings along with them. The senior player is usually a woman of grandmother status while the juniors are typically mothers in their late thirties whose children have reached maturity. Only at this stage of life can they find the time to devote to learning the epic which is very much a learning-by-doing process. Men are allowed to attend the ritual and some even become singers (called gurumai or gurubaba) but they are small in number. Singing is not the occupational specialisation of a particular group. Singers come from the Watchman/Musician/Herder (Ganda), Brasscaster (Gharva), Distiller (Kalar) and Gardner (Marar) communities among others. They do not get paid for singing, but the host of a performance is obliged to present gifts to them at the conclusion of the ceremony.

The second defining characteristic of the unity of the Dandakaranya epic tradition is the use of a hunting bow as a musical instrument. This is a very unusual form of musical instrument but is widespread throughout the western Dandakaranya region and, perhaps, a little beyond as well. The only reliable anthropological report of a similar tradition in India comes from the Kanya Kumari District of Tamil Nadu, of which more below.

In Bastar the bow is just one part of the instrument. The instrument the singers play in Kondagaon is an assemblage consisting of a twometre hunting bow (dhankul dandi), a bowstring (jhikan dori), a split bamboo comb for striking (chirani kari), an earthen pot (ghumra handi), a winnowing basket (dhakan supa) and a small stool (maci). The earthen pot is put on a stand made of straw (anyara or bendri), and the mouth of the pot is covered with a winnowing basket to form a resonator. One end of the bow is put on top of the basket and the other on the floor. The right-hand side of the bow has a serrated edge and the singer sits on the small stool with her left leg over the bow. She swishes the serrated edge of the bow with the bamboo comb to produce a steady rasping char-char-char-char-char. At the same time, she plucks the bow string with her left hand on the first and third beat. The result is a regular loud-soft-loud-soft-soft beat. Thus the instrument combines the functions of a musical bow, a musical rasp and a drum.

With the exception of the bow, the implements that make up the musical instrument are used on a daily basis in the kitchen. The winnowing basket is used to clean rice and other grains; the earthen pot is used to carry and store water; the bamboo sticks are used for sewing leaf cups and plates. The hunting bow was used in the past to hunt game in the forest and also as a weapon in fights and wars; today it is still used to hunt for birds and game in the forests.

During the performance of the Lachmi Jagar ritual these instruments become part of a sacred space but they acquire no special religious significance even though in the song the stools and the container are given names (Sonlata and Ruplata for the stools; Dumar for the container.) The central focus of the sacred space is a throne (gadi) upon which Mahalakhi, represented by a container of paddy, and Narayan, represented by a coconut, are placed for the purposes of worship. Performances of the Tija Jagar epic are also religious in nature but the element of fun and entertainment is much greater; there are no taboos surrounding the use of the bow for example. During a performance of Lachmi Jagar only the gurumai are allowed to sit on the stool and play but during Tija Jagar anyone can sit and sing. Indeed, playing the bow is encouraged during Tija Jagar because it gives would-be gurumai a chance to practise their skills.

The shape and functions of the various parts of the musical instrument undergo fascinating variations as one moves around the DNK region. In Nowrangpur, for example, the bow and stools are twice the size of those in Kondagaon. Furthermore, whereas the instruments used in Bastar are simply borrowed from the kitchen for the sake of the ritual, in Nowrangpur they are purpose-built and ritually immersed in water at the end of performance, at which time they sink to the bottom and stay there.

Interesting, too, is the variation in playing styles. In Bastar, as I have described above, the singer steadies the bow by throwing her leg over it, and plays it by plucking the string of the bow with her left hand and tapping out a beat on the bow with her right hand. In Nowrangpur, by way of contrast, the bow is not played at all. The singer steadies the bow between her two legs, holding the stick in a prayer-like position whilst singing.

Another difference is the size of the room. In Kondagaon the ritual is normally hosted by a householder who puts it on in the front room of his house. People come and sit and listen to the 
singing during the 7-11 days of the performance. The number in attendance can vary from one (for the host has to have one woman sitting next to the singers in front of the altar at all times) to fifty or more. In Nowrangpur, by contrast, the ritual is hosted by a village. However, there is no room for them to sit and listen to the singers. Indeed, on most occasions the singing is drowned out by the sound of drumming that accompanies the rituals performed in the courtyard outside the singing room. A performance I witnessed in Nowrangpur District reminded me of the Abelam painters of Papua New Guinea who spend months painting wonderful images which are destined to spend the rest of their lives in a darkened room in the middle of a male cult house.

The bow-song tradition of Tamil-speakers of south India, found only at the very southern tip of India, presents us with yet another variation in the use of the bow. Here the bow is played upside down (from a Bastar-centric perspective). These variations in bow-use provide a classic illustration, in material culture form, of LeviStrauss's theory of mythical variation. The upside-downness of Tamil bow-use is a fitting metaphor for the variation found in the content of the epics from the two areas: birth and life is the central ritual theme of the middle Indian epics; death and deification of the south Indian ones. As in middle India, singers can be male or female. The principal singers are always senior men in the south; women are allowed to sing and play but only from the age of sixteen to twenty five (Blackburn, 1988: 13). Birth is a theme of some of the Tamil epics but is, it seems, subordinated to the central theme of death.

\section{A PRELIMINARY ANALYSIS}

The epic tradition of the Dandakaranya plateau clearly has implications for an anthropological understanding of 'popular religion' in India but to develop these implications much more empirical research is needed. In Oral Epics in India Blackburn and Flueckiger noted 'no reported instances of women performing epic traditions alone' (Blackburn and Flueckiger, 1989: 9). I have searched the literature since then without success. I have no doubt that this situation is an artefact of a male bias in the collection of oral traditions and that many more instances of women's epic traditions will be discovered. For example, the indigenous peoples of the DNK have no written tradition but an exceptionally rich oral tradition. The prodigious labours of Verrier Elwin in the 1930s and 1940s documented some of this tradition. He spent two decades touring the entire DNK region conducting anthropological surveys and collecting oral traditions. He produced many volumes, eleven of which contain extensive collections of myths, stories and songs from different parts of the region. His early work was based in the northern region of the present state of Chhattisgarh where he published Songs of the Forest: The Folk Poetry of the Gonds (Hivale and Elwin, 1935), Folk-Tales of Mahakoshal (Elwin, 1944), Folk-Songs of Chhattisgarh (Elwin, 1946) and two ethnographies, The Baiga (Elwin, 1939) and The Agaria (Elwin, 1942) which, like all his ethnographic research, is extensively illustrated with mythical evidence. He then moved to Bastar District in southern Chhattisgarh where he published Myths of Middle India (Elwin, 1949) and his ethnography The Muria and their Ghotul (Elwin, 1947). Subsequent research took him to western Orissa where he published another two ethnographies (Elwin, 1950; Elwin, 1955) and Tribal Myths of Orissa (Elwin, 1954). This extensive archive of oral literature is but a tiny fraction of the extant tradition because, somewhat surprisingly, Elwin makes only one passing reference to the women's oral epic tradition that I have been able to find (1947: 188). This seems to have been due to his methodology. 'My custom,' he reports (1954: x), 'was to translate the stories on the spot, as they were narrated or interpreted to me.' 'The narrators,' he adds, 'were in the main elderly men, the headmen, priests and shamans of the village.' Some of the stories he collected from these men and reproduced are obviously potted fragments from the epics sung by women. For example, a brief 20-line myth about the origin of rice that Elwin (1954: 163-4) reproduces takes up 5200 lines of the Lachmi Jagar epic.

My fieldwork has been conducted in Kondagaon, Bastar District, Chhattisgarh. I first went there in 1982 to conduct a study on village marketing with Alfred Gell. I lived in Sargipalpara at the time. This was a village but is now part of the rapidly growing town of Kondagaon. It was there that I first heard Lachmi Jagar performed. In 1991 Jaidev Baghel and Harihar Vaishnav, both of whom live in Kondagaon, and I began a collaborative project on the oral traditions of 
Bastar. In 1996 Vaishnav recorded and transcribed the Lachmi Jagar sung by Gurumai Sukdai. This required some 36 hours of tape and yielded 30,929 lines of song. He also recorded Gurumai Sukdai's version of Tija Jagar, another epic which is sung in the wet season and which filled some 24 hours of tape. To provide a basis for comparison he recorded another version of Lachmi Jagar sung by Gurumai Raimati and Gurumai Ganmati of Khorkhosa, a village near Jagdalpur. The women of that village also sing an epic called Athe Jagar and he recorded that too. When we became aware that an epic called Bali Jagar was sung in the Nowrangpur District of Orissa we arranged for this to be recorded as well. Meanwhile, Jaidev Baghel recorded a version of the Tija Jagar epic sung by his uncle, Gurubaba Cheddiram. All in all, then, we have some 150 hours of tape. Over half of this has been transcribed but, to date, our work has centred on preparing a final translation of the Lachmi Jagar sung by Gurumai Sukdai. This has involved me and my colleagues in extensive fieldwork in India. Kondagaon has been the focus of my work but Harihar Vaishnav and I have made trips two short trips to Orissa to observe the Bali Jagar epic. (Harihar's paternal relatives came from Chhattisgarh but he has affinal relatives who live in Nowrangpur District.) Needless to say, our work is in its early stages but I am in a position to make a few preliminary comments about the distribution of these epics.

These towns where the epics are performed lie in the heartland of the DNK region. Jagdalpur $(19.06 \mathrm{~N}, 82.03 \mathrm{E})$, the capital of Bastar, lies on the Indrawati River as does Nowrangpur (19.23N, 82.5E). Kondagaon (19.6N, 81.67E) lies on the Narangi River some $72 \mathrm{~km}$ north of Jagdalpur. As the main focus of our research has been Kondagaon and district we are fairly confident that the northern and western boundaries of the Lachmi Jagar/Tija Jagar tradition are more or less defined by the boundaries of the district. The northern boundary is defined by the northern escarpment of the plateau and the western boundary by the Abujhmarh Hills. Epics are sung in the Abujhmarh Hills but they are sung by men not women (Savyasaachi, pers. comm.) The southern and eastern boundaries of the tradition are by no means clear and it is here that more research is needed before we can say anything with confidence. Another anthropological colleague, Tina Otten informs me that a Bali Yatra is performed in Koraput District, Orissa. It is possible that the natural boundaries of the DNK plateau define the outer limits of the tradition but, if the Kondagaon area is any guide, then internal cropping patterns within the region may also be important. This is because the epics develop their specificity by grounding all-India themes about the great deities - Mahalakhi, Parbati, Narayan, etc. in the local ecology, economy, history and society. I will illustrate this point by means of a very brief consideration of the role of polygyny in the story of Lachmi Jagar.

\section{THESTORY OF LACHMIJAGAR}

Many oral epics, as mentioned above, tend to be episodic in structure but a remarkable feature of the Lachmi Jagar epic is its classic narrative structure consisting of a clearly defined exposition, inciting moment, development, climax, denouement, final suspense, and resolution. This 'deep' structure lies under a 'surface' structure of four clearly defined 'books' (Longacre 1983: 22). The first book constitutes the prelude where the story of the origin of the world is told. The next two books constitute the exposition. This consists of two embedded narratives: the story of Mengin and the story of Parbati. The final book, the story of Mahalakhi, covers the development of the plot, the climax, denouement and resolution.

i) Exposition: King Meng (literally 'cloud') and Queen Mengin descended, at the queen's insistence, from the upper world to the middle world (earth). They were welcomed by the people on earth who make them their king and queen; they also built them a palace. Meanwhile, in another city in the middle world, Mahadev (i.e. Shiva), at his wife Parbati's insistence, established the first rice field. Due to a misunderstanding he set fire to the crop instead of harvesting it. The crop was partly burnt from whence came the different varieties of grain.

ii) Inciting moment and development: Queen Mengin, anxious to have a child, sent her husband to get a mango from Mahadev. He gave it on the condition that if a girl was born she would be married to his younger brother Narayan. Meng agreed, returned home and planted the mango. The tree grew and, following a first-fruits ritual, Mengin fell pregnant. A girl, Mahalakhi, was born and grew up. When she reached maturity she set up residence in Goppur. 
iii) Climax: Narayan, who was already married to Akisrani (literally 'Twenty-one Queens') and two other queens, insisted on marrying Mahalakhi. She was very reluctant to do so because she was afraid of what the jealous co-wives would do to her. Her father told her she must marry Narayan but it was agreed that the newly-married couple would live with Mahadev and Parbati after their marriage.

iv) Denouement and final suspense: Narayan lived with his new wife at his elder brother's place but, after some time, began to miss his other wives. He returned to visit them but then missed Mahalakhi so he abducted her in the middle of one night. They all lived together happily because Narayan never let Mahalakhi out of his sight. After some time, convinced that there would be no problems, he resumed his work at his court leaving all his wives at home together. The co-wives began to harass Mahalakhi by giving her impossible tasks to achieve. When she succeeded, thanks to the help of animal friends, they taught her to cook for Narayan. When she was not looking they added sand, cow dung, goat droppings, etc. to the food. Narayan forgave her the first time it happened but belted her with a stick on the second and third time. Unable to stand the situation any more, Mahalakhi left home via a tunnel dug by a rat.

v) Resolution: Famine gripped the king's household and the co-wives suffered much distress. The king went in search of Mahalakhi. After many adventures he found her and they were reconciled. He brought her back to the house, much to the delight of the co-wives, and she lived happily ever after sitting on her swing being waited on by the twenty-one queens.

Readers familiar with the Puranic tradition will immediately recognise the general themes that this story illustrates: Lakshmi's (Lachmi or Mahalakhi in Halbi) association with water, wealth (in this case rice) and prosperity; Shiva's (Mahadev) association with the distribution of seed and fertilisation, etc. But, as O'Flaherty has said, 'the universal elements of the myth are precisely the least important elements, that the point of the myth is to be sought in those areas in which the Hindu myth diverges from the general pattern' (1973: 15). The remarkable unity of the plot of Lachmi Jagar comes about because the epic is an extended allegory of the rice production process. The following symbolic equations, which are obvious to native speakers of Halbi, are necessary to get the general picture: Meng is monsoon rain, Mahalakhi is rice, the twenty-one queens are the various millets and pulses. The logic of the story implies other equations but I will restrict myself to these three here. I have already mentioned that Bastar is a polygynous society. It is necessary to add that the senior co-wife often becomes jealous of the new, younger, co-wife; but why are they identified with millet and rice respectively? Some facts about the geography of the DNK plateau can help to clarify this.

\section{THE MILLET/RICE FRONTIER ON THE DNK PLATEAU}

Geographers (Johnson, 2001) distinguish some 14 physiographic regions in India and the DNK plateau is one of four sub-regions in the 'Plateaus and Basins' category. Geographers differ on the precise boundaries of these regions but it suffices, for our purposes, to note that the DNK plateau is within 19-20N latitude and 81$82 \mathrm{~S}$ longitude, and that Kondagaon $(19.6 \mathrm{~N}$, 81.6E) lies in the middle of the Bastar-Jeypore plateau, the heartland of the DNK sub-region. This plateau, which varies in height between 550750 metres above sea level, is bounded by plains on all sides except to the east where the Eastern Ghats separate it from the coastal plains of Orissa. In travelling from east to west across this plain one gradually rises from the fertile plains of the Indrawati River at around 550 metres above sea level to the Abjuhmarh Hills which reach a height of 900 metres. The plateau remains one of the most heavily forested areas of India but a long history of human occupation has led, and continues to lead, to deforestation, open farmlands and bunded rice fields. It has been, and still is, relatively isolated. The main roads into the area are two: from the north, where one enters a forested plateau abruptly at Keshkal Ghat, and the east, where one descends onto the plateau through completely deforested hills. Forests and rivers have traditionally prevented access from the south and west. A recently built bridge over the Godavari River has opened up the southerly route; the eastern route to Maharahstra remains virtually inaccessible by road. The whole region lies within the tropics which means that temperatures do not drop to 
levels which endanger the rainfed-cultivation system. There are three distinct seasons: the hotdry months from March to June, the wet months from mid-June to October when the main crops grow, and the cold season from November to February when they are harvested. In mean terms the rainfall is adequate but there is, as Farmer (Farmer, 1965: 29) has put it, 'a most unwelcome tendency for rainfall to be inadequate ... at the beginning and end of the monsoon.'

Geographers also divide India into a ricegrowing east and a millet-growing west. The DNK region falls right on this boundary and its centre is defined by the intersection between this boundary and the one linguists draw between the Indo-European speakers of the north and the Dravidian speakers of the south. Of course, the cross on a map of India looks rather different at the district level. Here we find that in any one village in the region both languages may be found and both crops are always found. The nature of the coexistence, however, is different. Most farmers usually grow both types of grain but the proportions vary across the district, as do the methods of cultivation used. This reflects both the natural constraints of the landscape and the work farmers have done to transform it for their own purposes. The distribution of languages, however, reflects contingent historical factors and is in no way governed by climate or ecology.

The main millets grown are kosra (common millet, Panicum miliaceum), javar (sorghum, Sorghum bicolar), and mandiya (finger millet, Eleusine coracana). These are hardy wet-season crops that can be grown on hilly land and poor soils. Finger millet, for example, is productive on light soils and 'may be grown almost upon stones and gravel' (Church, 1886: 89). Rice, on the other hand, requires level, bunded fields and a lot of water. Thus rice, the principal cereal, finds its ecological niche in the flat river plains whereas the millets grow in the hilly areas. Common millet is the next most important cereal after rice and tends to predominate in the western region of the plateau with finger millet predominating in the north-eastern side and sorghum to the south.

The methods of production used vary from swidden cultivation of millet in the hills on the periphery to irrigated rice farming on the banks of the Indrawati River in the heart of the plateau. However, these two types of farming define the extreme ends of a continuum and most of the agricultural activity in the region occurs in the middle zones where we find different crop mixtures and farming methods coexisting.

An example of a village towards the rice end of the continuum is the village of Torand where I conducted some research. A small creek runs through this village and this is used by some farmers to irrigate vegetables on small bank-side plots. Bunded rice fields, watered by the monsoonal rains, work their way step-like up the slope. The lower fields are planted with highyielding, late varieties of rice and those higher up the slope with low-yielding, early varieties to ensure risks are spread in the event of unreliable rainfall. Higher up again the open undulating fields are planted with millet and pulses. The boundary of the village is marked by a reserved forest which, over time, has been encroached upon as the population expanded and the demand for farmland rose. This 'extensification' of agriculture proceeded apace with intensification as millet lands within the village were transformed into bunded rice fields. This village, it should be noted, contains both Dravidian and IndoEuropean speakers. They live in separate sections of the village but otherwise there is no significant difference between them in terms of the patterns of landownership and farming methods.

The village of Manjpur (see Gell, 1992), which also contains Dravidian and Indo-European speakers, provides an example of a farming system in the middle of the continuum. In this general area millet and rice are grown in more or less equal proportions. In Manjpur rice is regarded as the staple crop and the rice lands constitute the core of the village. This is surrounded by swidden lands, where millets are grown, and then by forests. The villagers are sedentary cultivators and the area devoted to the slashing and burning of forest for swidden cultivation purposes is confined to the outlying belt around the village called dipa. The land here is coarse-grained and stony in contrast to the soft clayey soils in the established rice fields. However, the villagers report (Gell, 1992: 31) that it is highly fertile and say that firing further stimulates the fertility.

The Hill Maria villages in the Abujhmarh Hills are at the millet end of the continuum. Common millet is the staple crop with maize and mustard important secondary crops. Late variety millets are grown on steep hill slopes which are cleared 
for the purpose and early varieties on the shallow slopes at the foot of the hills. The cleared plots are left fallow for two years and this fact, argues Savyasaachi (1993), sets up a distinct rhythm of socio-cultural activity that sets millet cultivation apart from annual cycles of socio-cultural activity that characterise rice farming. Rice cultivation, he notes, is now impinging on this system. The principal agents of change here are rice-farming migrants from outside who expropriate land and establish rice fields, and indigenous farmers, such as those found in Manjpur, who intensify their land use by converting swidden fields into rice land.

The millet/rice continuum in the DNK plateau can be visualised schematically as a series of concentric circles. The central circle contains the flat river plains and the good soils. Rice is the dominant crop. At the very centre of this inner circle are those villages on the river bank that irrigate the land to grow rice and vegetables. These villages are surrounded by those that practise rainfed-rice cultivation on the lower lands and grow millet as a side crop. As the radius increases the proportion of millet to rice grows, the land gets hillier and the soils poorer. On the periphery, in the hills, swidden cultivation of millets predominates. This spatial pattern is the product of historical change. Millet was the original crop. With increasing population, the lowland millet fields were levelled and turned into bunded rice fields. Millet was ousted and forced to take up residence on the periphery.

With these facts behind us, we are now in a position to make some sense of the story of Lachmi Jagar. Narayan's marriages to, firstly, the 21 queens (millet) and, secondly, to Mahalakhi (rice) are clearly related to the history of agricultural intensification in the area.

The distribution of Lachmi Jagar across the DNK plateau, as one might now expect, correlates with the distribution of rice cultivation. The epic is performed in the heartland of the plateau where rice is the dominant crop; but in the peripheral areas, where millet production outweighs that of rice, it is not to be found. The town of Kondagaon, where I worked, is in an intermediate zone on the millet/rice continuum and, as such, is on the westernmost boundary of the distribution of this oral tradition.

This fact is but a first step towards comprehending the Lachmi Jagar epic. The rice allegory is highly elaborated and one must understand the finer points of rice growing in Bastar to appreciate the story. To take a simple example, the two thrashings that Narayan gives Mahalakhi is clearly associated with the two thrashings that harvested rice gets to separate the grain from the chaff and the husk from the edible seed. This is reflected in the poetry of the song. For example the second thrashing, which removes the husk of the rice, is described in the following terms: 'The king gives her real beating/ He gives her a big thrashing / The queen's skin comes off' (aysa marai mare raja/ tinpur jhorai "jhore" anggur khala hite rani co).

It is important to note that for the women of Bastar the performance of the epic is a sacred ritual. Lachmi Jagar is not something one talks about, it is something that one experiences. These experiences are shared with other believers but vary according to the role one plays in the ritual. The mode of identification of the person with the part also varies. In many of the rituals people simply have fun but in others the actor is possessed by the spirit of the person he or she is playing. For example, when the singers sing of the arrival of the gurumai, the senior gurumai is possessed by the person she is singing about and when Mengin performs austerities the woman who acts this out becomes possessed. Some women of the audience become possessed when listening to the song in the evenings but audience participation is greatest on the day of Mahalakhi's wedding when large numbers of women of all ages fall into trances.

\section{CONCLUSION}

My principal concern here has been to quite literally put the oral epics of the women of the DNK plateau on the map and to show that, for one of the epics, Lachmi Jagar, the east/west frontier of rice and millet is of much greater cultural significance than the north/south language division. I have done this by giving a brief description of one version of the Lachmi Jagar epic and by trying to locate it in its broader context by contrasting it with other epics that I know of in this region. Whilst this outline has been sketchy, it is clear that we are confronted here with a female tradition which differs radically from the male traditions reported elsewhere. In order to develop the contrast between these two traditions much more work needs to be done in the DNK region, particularly in the districts of 
Nowrangpur and Koraput in Orissa. My colleagues and I have yet to transcribe, let alone translate, the epic we have recorded in Orissa and, as such, we only have a very superficial knowledge of the tradition there. However, until this comparative material is available our understanding of women's thought in this area, and subaltern thought more generally, will be found wanting.

The DNK region is a 'zone of relative isolation' to use Cohn's expression (1971: 2629). 'Relative' isolation does not mean 'complete' isolation, and the need for contrastive research of the kind emphasised above is balanced by the need for comparative research that finds parallels to these myth-rituals in other parts of India. Lakshmi (Lachmi or Mahalakhi in Halbi) is an allIndia goddess and the Bastar version of the epic is clearly a particular variation on a general theme. The singers identify the epic as a purana (ancient story) and there is some justification for this because the story has all the features of a classic Sanskritic purana. It is of interest that Lakshmi, one of India's most popular goddesses, has no Sanskritic epic glorifying her deeds. My colleagues and I did manage to find an Oriya version of a Mahalakshmi Purana in a bookshop in Nowrangpur. Marglin (1985: 207-211) contains a brief summary version of this epic, and her analysis of it offers a number of suggestive hypotheses concerning women, equality and the value question in India. An oral version of the Mahalakshmi Purana circulates in Bastar, and Gurumai Sukdai, the singer of the story of Lachmi Jagar summarised above, says that she sometimes sings it when performing Lachmi Jagar. It is important to stress that Gurumai Sukdai is illiterate and that neither she, nor any other singer we know in Bastar, is aware of the Oriya text. However, the summary version we have collected from her follows the Oriya version very closely. This story is quite different from the story of Lachmi Jagar outlined above but what they share in common is the pervasiveness of an ideology of equality between occupational groups. For example, the word caste (jat) does not appear once in the 120,000 words of Lachmi Jagar. Instead the word 'people' $(\log )$ is used; different groups are defined by using an adjective describing their occupation, such as 'blacksmith people,' 'carpenter people,' etc. In the epic these different groups always eat together, a significant fact given the role that rules of commensality play in defining hierarchy in elite ideology. This subaltern ideology of equality between groups stands in stark contrast to the inequality that characterises within-group relations. For the women singers of the DNK plateau this inequality is a complex set of household relations that is marked now by love and caring, now by jealousy and domestic violence.

KEYWORDS Oral epics; gender; Dandakaranya plateau; middle India; subaltern thought

ABSTRACT Anthropological studies of the oral epics of India are still in their infancy. Existing studies show that men are the principal singers. The songs they sing about reflect male concerns about wars and conquest; the rituals they perform whilst singing them tend to have death as a central theme. A contrary tradition, hitherto unreported, exists among the women singers of the Dandakaranya plateau of middle India who sing about birth, food production, and domestic violence. A preliminary mapping of these epics shows how they are grounded in the ecology of the Dandakaranya plateau and in the sociology of the patriarchal household. We can learn much about subaltern thought from these epics but before the theoretical implications of them can be developed much more primary research needs to be done, especially in the Nowrangpur and Koraput Districts of Orissa.

\section{REFERENCES}

Blackburn, S.H. 1988. Singing of Birth and Death: Texts in Performance. Philadelphia: University of Pennsylvania Press.

- 1989. Patterns of Development for Indian Oral Epics, in S.H. Blackburn, P.J. Claus, J.B. Flueckiger \& S.S. Wadley (eds), Orals Epics in India. Berkeley: University of California Press.

Blackburn, S.H., P.J. Claus, J.B. Flueckiger and S.S. Wadley (eds) 1989. Oral Epics in India. Berkeley: University of California Press.

Blackburn, S.H. and J.B. Flueckiger. 1989. "Introduction", in S.H. Blackburn, P.J. Claus, J.B. Flueckiger \& S.S. Wadley (eds), Orals Epics in India. Berkeley: University of California Press.

Church, A.H. 1886. Food-Grains of India. London: Chapman and Hall.

Cohn, B.S. 1971. India: The Anthropology of a Civilization. Englewood Cliffs: Prentice-Hall.

Elwin, V. 1939. The Baiga. London: John Murray.

.1942. The Agaria. Calcutta: Humphrey Milford.

_.1944. Folk-Tales of Mahakoshal. New York: Arno Press, 1980.

_.1946. Folk-songs of Chhattisgarh. Oxford: Oxford University Press.

.1947. The Muria and their Ghotul. Oxford: Oxford University Press.

.1949. Myths of Middle India. Oxford: Oxford University Press.

.1950. Bondo Highlander. Bombay: Oxford University Press. 
Elwin, V. 1954. Tribal Myths of Orissa. Oxford: Oxford University Press.

_.1955. The Religion of an Indian Tribe. Oxford: Oxford University Press.

Farmer, B.H. 1965. The Neglected Plateaus of Dandakaranya. Bombay Geographical Magazine 13, 21-39.

Flueckiger, J.B. 1996. Gender and Genre in the Folklore of Middle India. Ithaca: Cornell University Press.

Gell, S.M.S. 1992. The Ghotul in Muria Society. Reading: Harwood Academic Publishers.

Hivale, S. and V. Elwin. 1935. Songs of the Forest: The Folk Poetry of the Gonds. London: George Allen and Unwin.

Johnson, B.L.C. 2001. Geographical Dictionary of
India. New Delhi: Vision Books.

Longacre, R.E. 1983. The Grammar of Discourse. New York: Plenun Press.

Marglin, F.A. 1985. Wives of the God-King: The Rituals of the Devadasis of Puri. Oxford: Oxford University Press.

Nair, T.P. 1996. The Mango in Indian Life and Culture. 2 vols. Dehra Dun: Bishen Singh Mandra Pal Singh. O'Flaherty, W.D. 1973. Asceticism and Eroticism in the Mythology of Shiva. London: Oxford University Press.

Savyasaachi. 1993. "An Alternative System of Knowledge: Fields and Forest in Abujhmarh", T. Banuri and F.A. Marglin (eds), Who Will Save the Forests? Knowledge, Power and Environmental Destruction. London: Zed.

Author's Address: C. A. Gregory, School of Archaeology and Anthropology, Faculty of Arts, Australian National University, Canberra ACT 0200, AUSTRALIA E-mail: Chris.Gregory@anu.edu.au 